Lean Service, Business Strategy and $\mathrm{ABC}$ and Their Impact on Firm Performance

\author{
Wael Hadid \\ Sheffield University Management School, University of Sheffield, Sheffield, UK \\ w.hadid@sheffield.ac.uk
}

Accepted by Production, Planning and Control on 20 ${ }^{\text {th }}$ March 2019

http://dx.doi.org/10.1080/09537287.2019.1599146 


\begin{abstract}
This paper aims to address an underdeveloped area in the lean system literature by developing and testing a model which clarifies the current confusion on the role of different costing systems and business strategies in the implementation of lean service practices and their impact on financial performance. Using data from UK service firms, the proposed positive effect of lean service on financial performance is supported. Further, ABC has a positive impact on lean service, and therefore to indirectly on financial performance. Interestingly and in contrast to previous studies, both the differentiation and cost leadership strategies are directly and positively related to lean service. However, whilst $\mathrm{ABC}$ positively intervenes in the lean-differentiation relationship it suppresses the lean-cost leadership one resulting in a situation of inconsistent mediation.
\end{abstract}

Keywords: Lean Service; Activity-Based Costing; Business Strategy; Financial Performance. 


\section{Lean Service, Business Strategy and ABC and Their Impact on Firm Performance}

\section{Introduction}

The literature on lean system is still expanding and after establishing the significance of the system in relation to the performance of the adopting firms (e.g. Galeazzo and Furlan 2018; Shamsuzzaman et al. 2018; Hadid and Mansouri 2014), more attention has been devoted to the factors which facilitate/hinder the implementation of its practices (e.g. Bellisario and Pavlov 2018; Melin and Barth 2018; Tezel, Koskela, and Aziz 2018). This is not surprising especially due to the major changes brought about by lean practices and the investment needed to implement and maintain them (Swink and Jacobs 2012; Scherrer-Rathje, Boyle, and Deflorin 2009). Therefore, understanding how lean practices operate in relation to other organisational factors is of paramount importance (Melin and Barth 2018; Negrão, Filho, and Marodin 2017). However, an underdeveloped area concerns the role of costing systems and business strategy in the lean environment.

Firstly, some scholars in the management accounting literature argued, through theoretical or case studies, against the use of traditional costing systems (TCSs) in the lean environment as doing so would hinder the implementation of lean practices believed to be better supported by activity-based costing (ABC) or value stream costing (e.g. Li et al. 2012; Cooper and Maskell 2008; Datar et al. 1991). Whilst the results of such studies require further external validation as recommended by some of these scholars themselves, Fullerton and McWatters (2004) raised more concerns about their validity when they found that firms adopting advanced manufacturing systems including lean practices were still relying on TCSs. However, this latter study did not 
discuss whether firms keeping their TCSs were facing problems in the implementation of lean practices. Such confusing results leave researchers and practitioners unclear about the impact of keeping TCSs in the lean environment and the noticeable lack of evidence, based on large-scale quantitative studies, on this impact contributes to this deficiency in the lean system-cost accounting literature. This necessitates more studies in order to document sufficient evidence on the impact of different costing systems in the lean environment (Fullerton, Kennedy, and Widener 2014; 2013).

Secondly, there has been very limited attention to the role of business strategy in the lean environment and the four studies which attempted to contribute in this area reported completely different results. Whilst Baines and Langfield-Smith (2003) and Chenhall and Langfield-Smith (1998) found differentiators to engage with lean practices, Hallgren and Olhager (2009) and Qi, Zhao, and Sheu (2011) reported evidence to the contrary. In consequence, based on the available knowledge and limited empirical evidence, it is very difficult to make any conclusion about whether lean practices could be more favoured by firms focusing on cost efficiency or by those focusing on quality improvements or perhaps by both. In addition, the aforementioned studies did not attempt to offer explanations to their results and did not consider the potential role of costing systems in the strategy-lean association which also limits our understanding of why, for instance, cost leaders were found to implement lean practices in some studies but not in others.

In response to the above, this current paper aims to contribute by developing and testing a more complex theoretical model than in prior studies to offer more insights into the role of different costing systems and business strategy in the lean service environment (i.e. the use of lean 
practices by service firms) and their impact on firm performance. By doing so, the current study differs from prior studies in a number of ways and is expected to make the following contributions.

Rather than focusing on the role of each individual variable in isolation as in prior studies, their roles will be examined simultaneously in one model by integrating three different streams of literature; the lean-cost accounting literature, the lean-business strategy literature and the business strategy-cost accounting literature. By doing so, the current study, firstly, uncovers more complex relations than in prior studies by testing both the direct and indirect impact of business strategy on lean system through the costing systems used. Such complex relations will help offer some explanations to the mystifying results reported in the lean-business strategy literature. Secondly, the impact of different costing systems on lean practices will be documented in order to supplement the existing body of theoretical and case-studies (e.g. Li et al. 2012; Datar et al. 1991) with more evidence based on a large-scale quantitative study to test the external validity of their argument. Thirdly, whilst the cost accounting literature has failed to conclusively prove a positive relationship between the use of costing systems and firm performance (e.g. Maiga, Nilsson, and Jacobs 2014; Ittner, Lanen, and Larcker 2002; Mishra and Vaysman 2001), the current study proposes and tests the potential mediating role of lean practices in this relationship which has rarely been examined in either the costing or operations management literature (Banker, Bardhan, and Chen 2008).

The remainder of this paper is organised as follows. Some background information and literature on the three main concepts examined in this study and important for the hypotheses development 
are presented in section 2. The methodology, analysis and results are reported in sections 3 and 4 , respectively. Section 5 presents a discussion of the main findings and in the last section the conclusion, limitations and avenues for future research are provided.

\section{Literature and hypotheses development}

\subsection{Brief background information}

\subsubsection{Lean service}

Lean system is commonly defined as a multi-dimensional approach with principles and practices aiming to remove non-value-adding activities (NVAs) and improve customer value accordingly (Shah and Ward 2003; Bowen and Youngdahl 1998). The term "lean manufacturing" came into existence through a pioneering article by Krafcik (1988). Womack and Jones (1996) formally extended the concept of lean manufacturing to other functional areas by introducing the term "lean thinking" which was later extended to all service industries by formally coining the term "lean service" by Bowen and Youngdahl (1998).

Whilst the scope of the term "lean" has extended over time, the essence of the concept has remained the same. Like lean manufacturing, lean service seeks to eliminate waste from processes to improve customer value (Shamsuzzaman et al. 2018; Hadid, Mansouri, and Gallear 2016). It assumes that all organisations are comprised of a set of processes and activities which can be controlled and continuously improved (Allway and Corbett 2002). To implement lean service and achieve its goals, some principles and practices have been developed. Womack and Jones (1996) provided five general principles which can be used as a road map by practitioners: (i) value: focuses on identifying what is perceived by customers as valuable, (ii) value stream: requires the identification of all activities for producing/delivering products/services, (iii) flow: 
focuses on removing bottlenecks so that value-adding activities flow without interruptions, (iv) pull: work can only start when a customer places an order, (v) perfection: to continuously question the current processes and seek ways to improve them. To operationalise the five lean principles, several practices are used (e.g. 5S, value stream mapping, group technology, work load balancing, etc.), all of which concentrate on identifying and eliminating wasteful activities (Shamsuzzaman et al. 2018; Tezel, Koskela, and Aziz 2018; Shah and Ward 2003).

From a lean perspective and based on customer value, a company's activities can be classified into three classes (Hines and Rich 1997); (1) necessary value-added activities, (2) necessary NVAs (e.g. unpacking deliveries) and (3) unnecessary NVAs (e.g. work duplication). Lean service practices target the third category which is perceived as pure waste and point to the need to modify the current operational system in order to minimise and later eliminate the second group of activities. In the service environment, this may lead to considerable improvements. For instance, Atkinson (2004) studied eight functions in a financial company and found that about two hundred activities could be classified as wasteful activities in the form of rework and duplication, yet they comprised $40 \%$ of labour costs.

\subsubsection{Business strategy}

Business strategy can be defined as the way through which a company decides to compete in a selected market for competitive advantages (Porter 1980). Different typologies have been developed for classifying companies based on the approach they adopt (e.g. Gupta and Govindarajan 1984; Porter 1980; Miles and Snow 1978). 
Porter (1980) classified companies according to how they manage the five market forces into three strategic types. These include (1) cost leadership, (2) differentiation and (3) focus. The cost leadership strategy can be defined as 'an integrated set of actions taken to produce goods or services with features that are acceptable to customers at the lowest cost, relative to that of competitors' (Hitt, Ireland, and Hoskisson 2016, p. 118). On the other hand, the differentiation strategy is understood as 'an integrated set of actions taken to produce goods and services (at an acceptable cost) that customers perceive as being different in ways that are important to them' (Hitt, Ireland, and Hoskisson 2016, p. 121). The third category, the focus category, includes companies serving a segment of the market and competing through either the differentiation or cost leadership strategy. Therefore, this category is not an explicit strategy in itself (LangfieldSmith 1997).

Unlike differentiators, cost leaders operate in relatively stable markets, compete on a price basis, and produce a narrower range of standardised products/services (Ward et al. 2007; Porter 1980). Furthermore, according to the value chain literature, cost leaders and differentiators organise their value chains differently (Porter 1991). Cost leaders seek to organise activities and processes in their value chain so that they are carried out at the lowest possible cost (Porter 1985). In contrast, differentiators focus on how to organise and perform activities and processes in a way to look unique to customers (Porter 1985).

Porter's typology will be used in this study for a number of reasons. First, researchers carrying out survey studies need a simple typology for measuring business strategy that can be both easily communicated to managers and able to capture the complex gestalt of strategic attributes (Auzair 
and Langfield-Smith 2005). Porter's typology has extensively been tested and its simplicity and capability to capture complex relations have been proved (Miller and Dess 1993). Second, researchers have recognised the similarities between the Porter's typology and the other commonly used typology (defenders vs. prospectors) developed by Miles and Snow (1978). For instance, in her literature review article, Langfield-Smith (1997) found that cost leaders/defenders have similar control systems which are detailed, seek to reduce uncertainty, emphasise problem solving but not useful for new product development and/or capturing new market opportunities. In contrast, the control systems of prospectors/differentiators emphasise problem identification and flexibility to respond to their rapidly changing environment. Defenders/cost leaders are also found to link their reward systems to budget targets and to rely on formula-based rewarding systems. In contrast, differentiators/prospectors are more likely to use subjective evaluation for determining rewards (Langfield-Smith 1997). These similarities and others resulted in placing differentiators/prospectors at one extreme point of a continuum whilst cost leaders/defenders were positioned at the other extreme one, with different possible combinations of strategies lying in between (Chenhall 2003; Gosselin 1997). Therefore, even those who used the Miles and Snow's (1978) typology justified their decision based on these similarities (e.g. Gosselin 1997; Chong and Chong 1997) and used the findings based on the Porter's typology to build their hypotheses (e.g. Naranjo-Gil, Maas, and Hartmann 2009).

\subsubsection{Activity-based costing system (ABC)}

ABC systems were introduced in the 1980s to address the problems associated with the then used TCSs. The changes in the business environment, including higher levels of competition, more complex operations, increasing levels of automation and the production of more customised 
products/services, led to a substantial increase in the overhead costs (Johnson and Kaplan 1987).

This new environment has challenged the validity of TCSs which capture the consumption of overheads at a departmental level and then allocate them using mainly volume-based drivers (e.g. labour costs) (Cooper and Kaplan 1992).

A typical $\mathrm{ABC}$ system is usually defined as 'a method for accumulating product costs by determining all costs associated with the activities required to produce the output' (Qian and Ben-Arieh 2008, p. 807). In contrast to TCSs, typical ABC systems assume that products/services consume activities which, in turn, consume resources (Cooper and Kaplan 1992). Hence, ABC systems break down processes into their major activities, trace overhead costs to these activities and then use the most relevant cost drivers (volume-based and nonvolume based) to allocate the accumulated overheads to the final cost objects (Al-Omiri and Drury 2007). For proponents, the mechanism of ABC guarantees more precise measurement of the resources consumed by each product/service, which results in more detailed and accurate cost information (Cooper and Kaplan 1992). In addition, by decomposing processes into their major activities and recording their respective costs, $\mathrm{ABC}$ systems can support improvement initiatives by revealing NVAs which become the target for elimination (Maiga and Jacobs 2008). ${ }^{1}$

\subsection{Hypotheses development}

\subsubsection{ABC and business strategy}

Unlike cost leaders, the success of differentiators depends largely on their continuing

\footnotetext{
${ }^{1}$ Although some scholars have started to discuss the relevance of value stream costing or lean accounting to lean firms (e.g. Fullerton, Kennedy, and Widener 2014; 2013), the sample firms in this study did not indicate the use of such systems and hence these concepts were not discussed here.
} 
development of customised products/services which meet the demands of a wide range of customers (Ward et al. 2007; Porter 1980). This usually leads to more complex operations and substantial increases in overheads. Thus, differentiators may rely on $\mathrm{ABC}$ which can capture the complexity of their operations and provide a fair view of how resources are consumed (Gosselin 1997). Schoute (2011) found that companies with higher products/services diversity relied on $\mathrm{ABC}$ in order to capture the complexity resulting from placing different demands on companies' activities and resources. Ben-Arieh and Qian (2003) provided a good example of how ABC generates useful information about the activities carried out at the design and development stage of a product, which can be critical for differentiators. Moreover, whilst ABC can be an expensive system, differentiators are usually poised to invest in innovative systems (e.g. ABC) in their constant attempts to improve their flexibility and responsiveness to customer needs (Chenhall 2003; Chenhall and Langfield-Smith 1998).

In the case of cost leaders, the motivation for $\mathrm{ABC}$ is less clear than expected. On one hand, because cost leaders focus on cost efficiency, some may believe they should use ABC to help them understand how and where resources are consumed (Malmi 1999). On the other hand, cost leaders may prefer TCSs as they are comparatively cheaper to implement. In addition, TCSs may not generate largely distorted cost information for companies which operate in relatively less volatile markets and produce a range of relatively similar products/services as in cost leaders (Gosselin 1997).

Gosselin (1997) studied 161 manufacturing firms and found $\mathrm{ABC}$ to be more used by prospectors than defenders. Similarly, Baines and Langfield-Smith (2003) empirically 
demonstrated that firms with a differentiation strategy would require more advanced accounting systems such as ABC, and Chenhall and Langfield-Smith (1998) further demonstrated that ABC would generate more benefits to firms with a differentiation strategy than to firms with a cost leadership strategy. In contrast to cost leaders, $A B C$ is used by differentiators not only to control and manage costs but also to obtain more insights into the value-added activities essential to enhance product differentiation. More direct evidence on the strategy-ABC relation was reported by Malmi (1999), Bhimani, Gosselin, and Ncube (2005) and Naranjo-Gil, Maas, and Hartmann (2009). Malmi (1999) initially expected a positive ABC-cost leadership strategy association but his empirical analysis failed to confirm it. Bhimani, Gosselin, and Ncube (2005) examined the direct strategy-ABC relation using data from 416 firms in seven countries and a logistic regression. The findings indicated that the prospector strategy was positively associated with the implementation of ABC. However, Bhimani, Gosselin, and Ncube (2005) measured strategy as a dummy variable where " 1 " indicated a prospector strategy and " 0 " otherwise (including defenders). Therefore, the findings could also indicate that defenders, in general, did not favour ABC. Similarly, Naranjo-Gil, Maas, and Hartmann (2009) measured strategy on a semantic differential scale in which a low score indicated a defender strategy and a high score represented a prospector strategy. Using data from 98 firms, their findings revealed a positive effect of business strategy on the use of innovative management accounting techniques including $\mathrm{ABC}$. Taking into account the measurement method of the strategy variable, the finding could also imply that prospectors used $\mathrm{ABC}$ whilst defenders did not. Therefore, the following hypotheses are formulated:

H1: There is a direct positive relationship between the use of $\mathrm{ABC}$ and the differentiation strategy. 
H2: There is a direct negative relationship between the use of $A B C$ and the cost leadership strategy.

\subsubsection{Business strategy and lean service}

Joshi, Kathuria, and Porth (2003) have argued that operations strategy should be designed to support the overall business strategy, implying a potential influence of business strategy on the adoption of lean practices (Ward et al. 2007).

Lean service revolves around improving customer value and responding quickly to their changing needs (Shah and Ward 2003). Differentiators are likely to appreciate such a system. Due to their volatile market environment and the negative impact on productivity resulting from their focus on customisation (Kumar and Telang 2011; Gosselin 1997), differentiators can rely on lean practices to develop high quality products/services quicker in response to changes in customer needs (Kennedy and Widener 2008). In addition, all employees, in the lean environment, are responsible for quality control and quality issues which are encouraged to be addressed at source (Piercy and Rich 2009). This helps differentiators to improve productivity through avoiding or minimising rework time due to quality issues. In addition, by removing wasteful activities from processes, lean practices enable differentiators to shorten lead time which results in better responsiveness to customers (Shamsuzzaman et al. 2018); a necessary attribute for companies operating in volatile markets (Hadid, Mansouri, and Gallear 2016; Lei, Hitt, and Goldhar 1996). Furthermore, despite the ability of differentiators to compensate for additional costs by increasing prices, they still consider operating costs through their higher use of $\mathrm{ABC}$ for more relevant cost information (Naranjo-Gil, Maas, and Hartmann 2009). This provides an extra motive for firms with a differentiation strategy to adopt lean practices which 
help in controlling operating costs.

Cost leaders seek to protect themselves in the market by producing a narrower range of relatively similar products at low costs (Porter 1980). Operational efficiency becomes then essential and may encourage cost leaders to adopt lean service practices (Qi, Zhao, and Sheu 2011). An essential attribute of lean service is its focus on wasteful activities which, in service firms, may amount up to $40 \%$ of labour costs (Atkinson 2004). By eradicating NVAs, lean practices encourage service firms to do more with less (i.e. less capital, space and labour) (Swank 2003). For instance, lean practices emphasise the importance of performing tasks right first time. This improves employee productivity by reducing the time spent on rework activities along with all associated costs (Piercy and Rich 2009). Moreover, lean practices focus on improving the work environment by grouping activities and people needed for delivering similar products/services in the same area (Hadid, Mansouri, and Gallear 2016). This can help cost leaders reduce unnecessary movements of employees, which contributes to higher productivity and efficiency.

Surprisingly, whilst from a theoretical perspective both differentiators and cost leaders may have incentives to implement lean practices, the results of large-scale surveys have been confusing. Using data from 78 manufacturing firms, Chenhall and Langfield-Smith (1998) suggested that better performing firms adopted both the differentiation strategy and lean practices. Including a larger number of manufacturing firms (140 firms), Baines and Langfield-Smith (2003) concurred with Chenhall and Langfield-Smith (1998) by demonstrating that differentiators had a higher usage of innovative practices including Total Quality Management (TQM) and Just-in Time 
$(\mathrm{JIT})^{2}$. In contrast, Qi, Zhao, and Sheu (2011) collected data from 604 manufacturing companies and found that adopting the cost leadership strategy was positively associated with the implementation of lean practices and similar evidence was also earlier reported by Hallgren and Olhager (2009).

Apparently, there has been some confusion regarding the relationship between the different types of business strategy and lean practices. This problem was exacerbated by the lack of plausible explanations to the mixed results reported in prior studies, which necessitates further research in this respect. However, based on the theoretical argument presented above the following hypotheses will be tested:

H3: There is a direct positive relationship between differentiation strategy and the implementation of lean service practices.

H4: There is a direct positive relation between cost leadership strategy and the implementation of lean service practices.

\subsubsection{ABC and lean service}

Lean service practices revolve around the elimination of NVAs to improve processes (Shamsuzzaman et al. 2018; Womack and Jones 1996). However, TCSs do not facilitate the achievement of this goal by producing aggregate information and encouraging the absorption of all overhead costs into cost objects (Banker, Bardhan, and Chen 2008). Such a practice hides waste in overhead allocation rates and conceals areas for improvement (Chenhall and LangfieldSmith 1998). Datar et al. (1991) and ; Gurd, Smith, and Swaffer (2002) have highlighted through case studies how TCSs hold back improvement initiatives by generating misleading cost

2 They are considered parts of the lean system (Shah and Ward 2003) 
information on the effectiveness of process innovations which may lead managers to erroneously cease such innovations. In contrast, $\mathrm{ABC}$ records costs information at the activity level and uses more relevant cost drivers for allocation purposes (Cooper and Kaplan 1992). In consequence, $\mathrm{ABC}$ may equip managers with more detailed and relevant cost information which enhances their understanding of where and how resources are consumed (Cooper and Kaplan 1992). With this in mind, there are different ways through which $\mathrm{ABC}$ can support lean service.

First, by using activities as cost centres, $\mathrm{ABC}$ can be useful in differentiating between valueadded activities and NVAs, which is essential for lean service (Hadid and Mansouri 2014; Maiga and Jacobs 2008). Moreover, reporting quantitative measures of the costs consumed by each activity can be instrumental in (1) highlighting the need for management to implement lean practices to eradicate unproductive activities and (2) prioritising areas for improvement (Ittner, Lanen, and Larcker 2002). This is particularly important since Tezel, Koskela, and Aziz (2018) found that one of the main reasons behind the lack of implementation of lean practices was the inability of managers to develop a robust business case demonstrating clearly the potential benefits of these practices. Second, budgets and the associated variance analyses produced under $\mathrm{ABC}$ are thought to be more meaningful in highlighting the negative variances for lean practices to improve (Abu Mansor, Tayles, and Pike 2012). This ensures that lean practices are not implemented to improve already efficient processes. If lean practices are mistakenly used to improve efficient processes, this my subsequently lead to little or no improvement which, in turn, would damage the reputation of lean system and would ultimately result in the abandonment of this system (Banker, Bardhan, and Chen 2008; Datar et al. 1991). In its attempt to implement lean practices, Irving Oil moved to an activity-based budgeting system which highlighted to 
managers the amount of NVAs along with their associated costs (Carr, Lawler, and Reny 2012). Using the $\mathrm{ABC}$ concept was an eye-opener for Irving Oil managers and triggered attempts to modify the existing processes in order to eliminate NVAs. For instance, after moving to an ABCbased budgeting, the company realised that about $\$ 1$ million a year was spent on reconciliation activities which did not add value. Removing these NVAs resulted in savings of $\$ 17$ million in 2011 which increased to \$30 million in 2012 (Carr, Lawler, and Reny 2012).

To date, there has been very little effort to provide empirical evidence through large-scale survey studies on the role of different costing systems (e.g. TCSs vs. ABC) in the lean environment (Fullerton, Kennedy, and Widener 2014, 2013; Banker, Bardhan, and Chen 2008). In addition, mixed results were reported in this body of literature. Fullerton and McWatters (2004) surveyed manufacturing firms and found that firms adopting advanced manufacturing systems including lean practices were still relying on TCSs. However, the authors did not discuss whether firms keeping their TCSs were facing problems in the implementation of lean practices. In contrast, Innes and Mitchell (1995) found the UK's largest companies engaging in improvement programmes including continuous improvement, TQM and JIT to be also using ABC. Negrão, Filho, and Marodin (2017), in their literature review study, concluded that TCSs could have a detrimental effect on the implementation of lean practices and hence they should be avoided. Banker, Bardhan, and Chen (2008) studied 1250 manufacturing plants and found that those using $\mathrm{ABC}$ had a higher implementation level of lean practices which, in turn, improved firm performance. Evaluating the mixed results presented above, the following hypothesis will be tested. 
H5: The use of $\mathrm{ABC}$ is positively related to the implementation of lean service practices.

\subsubsection{Lean service and firm performance}

Lean service is designed to improve processes by focusing on NVAs from customer perspective (Hadid, Mansouri, and Gallear 2016; Shah and Ward 2003). The basic premise of the system is that by eliminating NVAs, several benefits can be achieved including a reduction in operating costs, higher productivity and efficiency, improved flexibility, enhanced customer satisfaction and profitability (Nielsen, Kristensen, and Grasso 2018; Shamsuzzaman et al. 2018; Agarwal et al. 2013). Several practices can usually be used to target NVAs such as standardisation, automation, 5S, process redesign, etc. ${ }^{3}$ (Hadid and Mansouri 2014). The effectiveness of these practices, and others, in delivering the aforementioned benefits has been the subject of ongoing debate among researchers (Galeazzo and Furlan 2018; Nielsen, Kristensen, and Grasso 2018; Shamsuzzaman et al. 2018; Hadid, Mansouri, and Gallear 2016). For example, Cua, McKone, and Schroeder (2001) classified lean practices into three bundles (i.e. TQM, JIT, and Total Preventive Maintenance (TPM)) and investigated their joint impact on manufacturing performance. Their results highlighted the importance of implementing lean practices as a system and their capability to improve the manufacturing performance. Shah and Ward (2003) extended the work of Cua, McKone, and Schroeder (2001) by using a larger sample (1757 manufacturing plants) and adding a fourth bundle (Human Resource Management) into the analysis. Their findings confirmed earlier results and highlighted the positive role of each of the lean bundles in enhancing operational performance. Alsmadi, Almani, and Jerisat (2012) empirically

\footnotetext{
${ }^{3}$ A glossary sheet which contains a definition for each lean practice included in this study can be found in Hadid and Mansouri (2014).
} 
demonstrated that although some differences existed in the implementation of lean practices between manufacturing and service firms, lean practices improved the financial and operational performance of adopters in both sectors. Agarwal et al. (2013) reported slightly different results indicating that lean practices could influence only some performance measures (i.e. sales, profit and profit margin). Based on the above:

H6: There is a direct positive relation between the implementation of lean practices and firm performance.

Figure 1 depicts the research framework which highlights the associations between the main constructs and two important points. More specifically, integrating the arguments for $\mathrm{H} 1, \mathrm{H} 2$ and $\mathrm{H} 5$ brings to light the $\mathrm{ABC}$ intervening impact in the strategy-lean relationship. Based on that, a full understanding of how business strategy influences lean service can be gained by considering its both direct as well as indirect effect through $\mathrm{ABC}$ and this will help to explain the mystifying results in this stream of literature as shown later. In addition, combining the arguments for H5 and H6 highlights the role of lean practices in mediating the ABC-performance relationship which the cost accounting literature could not adequately prove. In contrast to what the direct effect suggested by previous studies (e.g. Maiga, Nilsson, and Jacobs 2014; Mishra and Vaysman 2001), the theoretical model depicted in figure 1 points to a potential mediating effect of lean practices in the ABC-firm performance relationship which has not been sufficiently examined in the literature (Banker, Bardhan, and Chen 2008).

\section{$<<$ Figure 1: The research framework $>>$}




\section{Methodology}

\subsection{Sample selection and data collection}

For testing the research model, data were collected from UK for-profit private service firms ${ }^{4}$. Using the Financial Analysis Made Easy (FAME) database, a sample of one thousand firms was randomly drawn which had to meet the following criteria: (1) had to have unconsolidated information in the last three available years prior to 2012 in which the study was carried out and (2) had to employ greater than fifty employees to ensure the sample firms were large enough to expect advanced systems such as ABC and lean system to be in use (Mia and Winata 2008).

A questionnaire was prepared and pilot tested with two academics and thirteen practitioners to check the face and content validity of the variables/constructs and some amendments were applied to improve the questionnaire accordingly. The questionnaire, a prepaid envelop and personalised letter were distributed to the sample firms targeting positions such as chairman, CEO, operations director or finance director. To avoid different interpretations of lean practices, an A4 sheet which included a definition of lean practices as recently published by Hadid and Mansouri (2014) was also in the package. A second letter was posted to all non-respondents after three weeks from the first contact and followed by a telephone call to all non-respondents to encourage them to participate. To improve the response rate, a summary of the results was promised to all participants.

Of the one thousand questionnaires distributed, seventy were returned because of wrong

\footnotetext{
4 The same dataset used in this study was also used in Hadid, Mansouri, and Gallear (2016). However, all five hypotheses relating business strategy, $\mathrm{ABC}$ and lean system have not been tested in the previous paper.
} 
addresses $^{5}$. Of the 930 delivered questionnaires, 186 were received and later reduced to 105 as 81 questionnaires were returned empty for different reasons ${ }^{6}$ resulting in a response rate of 11.3\%. Six questionnaires were further eliminated due to high missing data leaving 99 questionnaires in the sample. The response rate is comparable to that of recent surveys such as the $7.9 \%, 10.6 \%$ and $14.9 \%$ obtained by Inman et al. (2011), Kim, Kumar, and Kumar (2012) and Auzair and Langfield-Smith (2005), respectively.

The sample distribution per industry included twenty firms form the financial industry, nine from education, sixteen hotels and restaurants, eight from the post and telecommunication, and six, sixteen and twenty four firms from the transport, wholesale and retail, and other services, respectively. Respondents had on average seventeen years of experience in their management position and nine years at their current firm, which could be a positive indication about the credibility of the collected data.

To test for non-response bias, ANOVA analysis was performed on two variables; firm age and turnover (e.g. De Leeuw and Berg 2011; Craighead, Hult, and Ketchen 2009). For a more accurate analysis, 99 firms were randomly selected from the non-respondents group and used in the ANOVA analysis (Hair et al. 2010). Statistically speaking, no significant differences between the two groups were detected suggesting that non-response bias would not be a significant threat in this study. A further test was conducted using the wave method as in Maiga, Nilsson, and

\footnotetext{
${ }^{5}$ A similar problem faced Kroes and Ghosh (2010) and Al-Omiri and Drury (2007) where 469 and 102 questionnaires were returned for a similar reason.

6 No time (21), the targeted person left the firm (20), the scope of the study does not apply to the targeted firm (18), company policy not to participate (9), small company (8), information required is sensitive (3), and the company participated in many studies recently (2).
} 
Jacobs (2014). Under this method, responses from early and late respondents are usually compared as the latter are believed to have similar characteristics to non-respondents ${ }^{7}$. Using Chi Squared test in relation to industry $(\mathrm{p}=.81)$ and costing systems $(\mathrm{p}=.35)$ provided further evidence of the lack of differences between the two groups. Likewise, ANOVA analysis tested for potential differences between the two groups on lean service and business strategy items and no significant differences were found.

To test for potential common method bias, Harman's single-factor test was used (Podsakoff et al. 2003). In this technique, all variables are loaded into an exploratory factor analysis with focus on the unrotated solution. The common method bias is not a serious issue if no single factor explains a large proportion of variance (Podsakoff et al. 2003). Following this logic, the factor analysis extracted ten factors with only $23 \%$ variance explained by the first factor. This could be a reasonable assurance about the lack of common method bias in this study.

\subsection{Variables measurement}

To measure lean service, taking into account its multidimensional nature as explained in subsection 2.1.1, the 37 practices presented along with their associated references in Hadid and Mansouri (2014) were used. However, to ensure that a practice was an important component of lean service, only practices mentioned by at least five articles were included in this study. Accordingly, 23 lean service practices were considered and their implementation level was measured using the six-point scale by Fullerton, McWatters, and Fawson (2003). The implementation year of lean service was also solicited.

7Therefore, the wave method does not measure the actual non-response bias but only provides a proxy for it. 
Business strategy was measured through the scales used by Auzair and Langfield-Smith (2005). A low score on both scales refers to lower levels of emphasis on the corresponding strategy. The costing system was measured following the literature (e.g. Maiga, Nilsson, and Jacobs 2014; Banker, Bardhan, and Chen 2008; Gosselin 1997), by asking participants to report the costing system employed by their firm. Respondents who declared the use of ABC were coded 1 and all other respondents were coded 0 in the dummy variable used in the main analysis as in Maiga, Nilsson, and Jacobs (2014) and Banker, Bardhan, and Chen (2008).

Firm performance has been conceptualised and operationalised in different ways and some researchers have pointed to the multidimensionality nature of firm performance. For instance, Venkatraman and Ramanujam (1986) developed a scheme which classified firm performance into three categories (1) financial performance, (2) operational performance and (3) firm effectiveness which concerns meeting the demands of a wider range of stakeholders. In the accounting literature, Kaplan and Norton $(1992,1996)$ promoted measuring performance through their balanced scorecard (BSC) which has four different perspectives; learning and growth perspective, internal process perspective, customer perspective, and finally the financial perspective. Their main argument was that financial measures/indicators are backward looking and lag operational measures and hence they may not draw a true and fair picture of firm performance.

However, financial performance indicators (collected from the FAME database) were used in this study for the following reasons. Firstly, measuring the three non-financial, operational 
perspectives in Kaplan and Norton's BSC can be difficult through objective data due to the lack of publicly available data on private firms similar to the ones used in this study. Using secondary, externally-audited data on the dependent variable (i.e. firm performance) was deemed to be important to mitigate the effect of the potential bias arising from relying solely on one source of information (e.g. questionnaire) and from one respondent per firm (Swink and Jacobs 2012). Secondly, one of the objectives of this study was to examine the mediating role of lean service in the confusing $\mathrm{ABC}$-performance relationship, in which firm performance was measured in prior studies from a financial perspective (e.g. Maiga, Nilsson, and Jacobs 2014; Ittner, Lanen, and Larcker 2002; Mishra and Vaysman 2001). Hence, focusing on financial performance in this study helps to isolate the potential impact of using different performance dimensions and makes our results more comparable to those of prior studies on the $\mathrm{ABC}$ performance relationship (e.g. Maiga, Nilsson, and Jacobs 2014; Ittner, Lanen, and Larcker 2002; Mishra and Vaysman 2001).

Financial performance was operationalised through data on profit per employee and return on capital employed (Agarwal et al. 2013; Bhasin 2012) and consideration was given to the implementation year of lean service. The data collected indicated that lean service in the responding firms was implemented, on average, in 2009. Accordingly, data on the financial indicators were obtained on all available years since the implementation year ${ }^{8}$ (i.e. up to 2011). To control for potential industry bias, we followed Swink and Jacobs (2012) and Patterson et al. (2004) by computing and using an industry-adjusted median value for the firm performance

\footnotetext{
${ }^{8}$ Doing so is an attempt to partially address the potentiality of reverse causality (Guest et al. 2003).
} 
variables ${ }^{9}$.

Furthermore, for more robust analyses and results, three-year past data (preceding the year of lean service implementation) on the two financial indicators were collected, based on which an industry-adjusted median value was constructed to account for past performance effects ${ }^{10}$ (Swink and Jacobs 2012; Patterson et al. 2004). Finally, firm size was considered as an important control variable (Mia and Winata 2008; Shah and Ward 2003), and was operationalised by calculating the three-year average total number of employees in the period preceding the implementation year of lean service.

\section{Data analysis}

An exploratory factor analysis was applied on lean service practices to reduce the data and establish the main dimensions (Shah and Ward 2003). Varimax rotation, eigenvalue $>1$, KaiserMeyer- Olkin test for sampling adequacy (> 50\%), communality value of $\geq 50 \%$ for each item in a scale and loadings $>55 \%$ were all applied as suggested by Hair et al. (2010). Items with cross loadings and/or not meeting the above thresholds were dropped from further analyses. The reliability of multi-item constructs was assessed through Cronbach's alpha (Nunnally 1978). An examination of the assumptions of parametric tests revealed six lean practices (bold in the appendix) which were highly skewed $(p<.001)$ and consequently they were dropped leaving 17 lean practices.

\footnotetext{
${ }^{9}$ To compute an industry-adjusted median value for a firm, the industry median value of a performance indicator (e.g. profit per employee) was obtained from the FAME database and was subtracted from each firm's median value on that performance indicator.

10 This is also useful to account for cases where past performance explains the implementation of an innovation system such as lean service (Guest et al. 2003; Gurd, Smith, and Swaffer 2002).
} 
The seventeen lean practices were reduced into four factors, named process factor (PF), physical structure factor (PSF), customer value factor (CVF) and error prevention factor, respectively, explaining $62 \%$ of the variance. Practices loading ranged from $60 \%$ to $83 \%$ with communality values of over $50 \%$ and Cronbach's alpha values between $68 \%$ and $83 \%$. However, "mistake proofing" was removed for having insignificant loading on any of the four factors. More detail on the results of this factor analysis could be found in table 3 in Hadid, Mansouri, and Gallear (2016).

By adhering to the criteria of Hair et al. (2010), the convergent and discriminant validity of factors were ensured. All items in a factor loaded significantly on that factor and did not have significant cross loadings on other factors.

The main analysis was carried out by employing partial least squares structural equation modeling (PLS-SEM) which was deemed appropriate for two reasons (Hair, Ringle, and Sarstedt 2011). First, PLS-SEM can tackle non-normally distributed data and produce unbiased estimates (Hair, Ringle, and Sarstedt 2011). This is important in this research given the use of objective financial data ${ }^{11}$. Second, because it is a variance-based technique, PLS-SEM has a softer demand in terms of sample size compared to other techniques such as the covariance-based SEM (Hair, Ringle, and Sarstedt 2011, Hair, Sarstedt, and Ringle 2012). The minimum sample size for PLSSEM is usually determined by multiplying the largest number of structural paths associated with

11 Both the Kolmogorov-Smirnov and Shapiro-Wilk tests $(\mathrm{p}<.001, \mathrm{df}=99)$ indicated that the financial indicators violate the normality assumption. A visual inspection of histogram graphs also confirmed the violation of the normality assumption. 
an endogenous latent construct by ten (Hair, Ringle, and Sarstedt 2011). In this study, the most complex construct is the return on capital employed as five structural paths are pointing to it ${ }^{12}$ (three lean factors, firm size and past performance). Hence, a sample size of 99 is almost double the minimum sample size suggested by the above-mentioned rule (10*5 $=50$ observations).

\subsection{Validity and reliability}

The validity of each construct was assessed by examining its indicators loading and average variance extracted, whilst composite reliability $(>70 \%)$ was evaluated to ensure the reliability of each multi-item construct (Hair, Ringle, and Sarstedt 2011). As evidenced in table 1, the reliability of all constructs surpassed the recommended value of $70 \%$. In addition, most items measuring the lean factors had loadings on their associated factor of $>70 \%$ and all items had loadings of $>55 \%$ (see table 1 ). This provided initial assurance regarding convergent validity. However, the item "root cause analysis" in the two-item error prevention factor did not have a significant loading and therefore was dropped from further analysis along with its factor.

\section{<<Table 1: The measurement model>>}

Based on that, only three factors have represented lean service in the final analysis as shown in table 1 . The average variance extracted reported in table 1 offered further evidence on the convergent validity of each construct. In all cases, the average variance extracted was $>50 \%$ and in line with Hair, Ringle, and Sarstedt's (2011) recommendations. In addition, as shown in table 2, the square root of the average variance extracted of each construct exceeds its correlations with other constructs which is evidence of discriminant validity (Hair, Sarstedt, and Ringle

12 For profit per employee only four structural paths are directed at it. These include all structural paths directed at the return on capital employed except firm size. 
2012).

\section{$<<$ Table 2: Correlations matrix $>>$}

\subsection{Results of hypotheses testing}

To assess the structural model and the proposed relationships, $R^{2}$, coefficients $(\beta)$ along with their significance and the model's predictive capability $\left(\mathrm{Q}^{2}\right.$ : cross-validated redundancy) were examined $^{13}$ (Hair, Sarstedt, and Ringle 2012). Since PLS-SEM does not assume multivariate normality in the data, it relies on the bootstrapping method and produces t-value for evaluation purposes (Hair, Ringle, and Sarstedt 2011). To improve the robustness of the results, the structural model was estimated with the bootstrapping function set to 5000 samples (Hair, Ringle, and Sarstedt 2011).

Table 3 (panel A) reports the results of the structural analysis and figure 2 depicts visually the structural model. The results suggest an acceptable model with all $\mathrm{R}^{2}$ values being greater than the minimum 10\% recommended for practical and statistical significance (Lee et al. 2011; Falk and Miller 1992). In addition, the predictive capability of the model is supported with all crossvalidated redundancy values being larger than zero (Hair, Ringle, and Sarstedt 2011, Hair, Sarstedt and Ringle 2012).

The findings (table 3) demonstrate a positive relationship between $\mathrm{ABC}$ and the differentiation strategy $(\beta=.31, p<.001)$ and a negative ABC-cost leadership association $(\beta=-.30, p<.01)$ which support $\mathrm{H} 1$ and $\mathrm{H} 2$. Further, the differentiation strategy is positively related with two lean

\footnotetext{
${ }^{13} \mathrm{R}^{2}$ and $\beta$ in PLS-SEM are interpreted in a comparable way to those reported in OLS regression analysis (Hair, Ringle, and Sarstedt 2011; Hair, Sarstedt, and Ringle 2012).
} 
service factors $^{14}$, namely the $\operatorname{PF}(\beta=.21, p<.05)$ and the $\operatorname{CVF}(\beta=.23, p<.05)$ which supports H3. The cost leadership strategy is also positively and directly related with two lean service factors, namely the PF $(\beta=.29, p<.01)$ and PSF $(\beta=.29, p<.01)$ which support H4. H5 is also supported since $\mathrm{ABC}$ is positively and directly related to the $\mathrm{PF}(\beta=.20, p<.05), \mathrm{CVF}(\beta=.20$, $p<.05)$ and PSF $(\beta=.29, p<.01)$. Finally, lean service seems to be promising given its positive impact on the return on capital employed through its $\operatorname{PF}(\beta=0.20, p<.01)$ and on profit per employee through its $\operatorname{PSF}^{15}(\beta=0.18, p<.05)$, which is in line with H6.

The indirect effects of business strategy on lean factors through $\mathrm{ABC}$ and that of $\mathrm{ABC}$ on firm performance through the lean factors were formally tested using the bootstrapping method. The method was found more relevant for small sample sizes and/or for data which did not meet the multivariate normality assumption (Malhotra et al. 2014; Preacher and Hayes 2008); both aspects apply to the current study. The bootstrapping method was used with 5000 samples with replacement in order to construct an empirical distribution of the product term for each indirect relation (e.g. differentiation $-\mathrm{ABC}-\mathrm{PF}$ ) using only the significant direct paths. Each of the empirical distributions was then order-ranked and the percentage above/(below) zero for negative effects/ (positive effects) was calculated to determine the statistical significance of the relations (Preacher and Hayes 2008). The results of this process are presented in table 3 (panel B). The results suggested a negative indirect association between the cost leadership strategy and all lean service factors. In contrast, a positive indirect association between the differentiation

\footnotetext{
${ }^{14}$ In the hypotheses development section all hypotheses were formulated in relation to the lean service as a whole concept and not to its constituent factors. This was necessary as the constituent factors of lean service were not known before conducting the exploratory factor analysis. Future research may rely on the factors developed in this study to ideally formulate hypotheses in relation to each individual factor of lean service.

${ }^{15}$ Although the direct impact of ABC on performance was not hypothesised in this study, another model which incorporated this impact was also tested. However, similar to the findings of Banker, Bardhan, and Chen (2008), no support for the direct impact was found.
} 
strategy and the three lean service factors was found. Evidence was also found confirming the mediating role of lean service factors in the $\mathrm{ABC}$-performance relation. The PF mediated the impact of $\mathrm{ABC}$ on the return on capital employed and the PSF mediated the ABC-profit per employee relation as shown in table 3 (panel B).

\section{<<Table 3: Results of hypotheses testing>>}

\section{$<<$ Figure 2: The structural $\operatorname{model}^{16}>>$}

\section{Discussion and implications}

This research has attempted to shed light on the role of costing systems and business strategy in the lean environment and their impact on firm financial performance. The findings verify the promising effect of lean service on financial performance (H6). Two of the lean service factors (PF and PSF) are found to positively influence profit per employee and return on capital employed even after controlling for the potential effect of past performance, industry and firm size. This evidence supplements earlier studies (e.g. Alsmadi, Almani, and Jerisat 2012) and should encourage service firms to experiment with and benefit from lean service practices.

\subsection{Lean service, $A B C$ and firm performance}

The findings indicate that there is a positive relation between $\mathrm{ABC}$ and lean service (H5) and by extension a negative relation between TCSs and lean service. This is in line with the argument that $\mathrm{ABC}$ enhances the visibility and awareness of how resources are expended at the activity level, which helps to highlight NVAs for lean practices to eliminate (e.g. Maiga and Jacobs 2008). Therefore, the support for H5 contradicts the findings by Fullerton and McWatters (2004)

\footnotetext{
${ }^{16}$ Control variables (past performance and firm size) were not included for simplicity.
} 
and suggests that using TCSs may hinder the implementation of lean practices (Datar et al. 1991). Moreover, panel $\mathrm{B}$ in table 3 indicates that $\mathrm{ABC}$ has a significant indirect relationship with financial performance through lean service practices. This corroborates earlier evidence reported by Banker, Bardhan, and Chen (2008) and extends it in two ways. Banker, Bardhan, and Chen (2008) found lean practices to mediate the effect of $\mathrm{ABC}$ on the operational performance of manufacturing plants. However, the current findings indicate that lean practices will perform the same role in service firms and with financial performance.

Such findings contribute to our theoretical understanding of the mediating role of lean practices and the ways by which $\mathrm{ABC}$ generates benefits to the adopting firms through these practices (e.g. Maiga, Nilsson, and Jacobs 2014; Mishra and Vaysman 2001). The findings suggest that $\mathrm{ABC}$ (alone) may not be able to significantly enhance financial performance. However, by using ABC two goals can be achieved simultaneously. First, more relevant and detailed cost information for decision making will be attained. Second, the information generated by ABC will indirectly impact financial performance by supporting the implementation of lean service practices which are effective in improving firm financial performance. In addition to their theoretical contribution, these findings have also an important practical implication for managers. Service managers should avoid relying on TCSs if they are implementing or contemplating the implementation of lean service practices in their operations and should use $\mathrm{ABC}$ which is more conducive to the lean environment. Achieving that may require some interaction between the accounting and operations management functions in order for each to explain their plans and needs which may help to minimise unpleasant surprises during the implementation process of lean practices. 


\subsection{Business strategy and lean service}

Both differentiation (H3) and cost leadership (H4) are found to have a direct positive relation with lean service factors. However, the set of lean practices associated with each type of strategy is not necessarily the same which may reflect the distinctive perspective of each strategy. Cost leaders normally focus on reducing operating costs and improving the efficiency of their processes. Therefore, they have implemented the PF and PSF to help in achieving this aim. On the other hand, differentiators pay more attention to understanding customer requirements which enables them to provide unique products/services. As a result, differentiators have focused on the CVF which goes in line with their objective. However, differentiators have also implemented the PF in their attempt to eliminate waste from processes, which implies that differentiators do not entirely ignore operating costs (Qi, Zhao, and Sheu 2011; Chenhall and Langfield-Smith 1998).

The focus on different lean practices by the two different business strategies possibly explains the mixed results reported in prior research (e.g. Qi, Zhao, and Sheu 2011; Baines and LangfieldSmith 2003; Chenhall and Langfield-Smith 1998). More specifically, the different and narrow representations of lean system in prior empirical studies have probably contributed to the inconclusive results. For instance, if researchers focus on lean practices incorporated into the CVF, they would more likely confirm a positive differentiation strategy-lean system fit (e.g. Baines and Langfield-Smith 2003; Chenhall and Langfield-Smith 1998). On the other hand, if they focus on lean practices incorporated into the PSF, they would more likely find a positive lean system- cost leadership strategy fit (e.g. Qi, Zhao, and Sheu 2011). In short, lean service is a multi-dimensional system and should be represented accordingly in order to understand its relationship with other variables. 


\subsection{Lean service, business strategy and $A B C$}

The results indicate that whilst the differentiation strategy directly and positively affects lean service (H3), it also has an indirect influence on all lean service factors through $A B C$ as indicated by (H1 and H5) and statistically confirmed in table 3 (panel B). This implies that ABC partially mediates the lean-differentiation strategy relationship which empirically validates the argument that differentiators operating in uncertain environments and producing more customised products are more likely to rely on ABC (Chenhall and Langfield-Smith 1998; Gosselin 1997). This, in turn, enables the implementation of lean service practices to further enhance their performance (Banker, Bardhan, and Chen 2008).

The results also confirm an indirect, though negative, effect of the cost leadership strategy on lean service as shown in table 3 (panel B). As noted by some scholars (e.g. Naranjo-Gil, Maas, and Hartmann 2009; Bhimani, Gosselin, and Ncube 2005; Malmi 1999) and further confirmed in this study (H2), cost leaders are less likely to rely on ABC since it is expensive to implement and it does not substantially improve the quality of information under stable environments and when a narrower range of standardised products is produced. Consequently, the cost leadership strategy is proved to have a direct positive impact on lean service (H4) and an indirect negative impact (H2 and H5) due to the adoption of TCSs. This has a detrimental effect on lean service. Put it differently, the $A B C$ variable in this study is found to suppress the impact of the cost leadership strategy on lean service resulting in a case of inconsistent mediation (MacKinnon, Krull, and Lockwood 2000).

Inconsistent mediation represents cases where an independent variable (e.g. cost leadership 
strategy) has both a direct and indirect impact on a dependent variable (e.g. lean service) but with different signs (Taylor, MacKinnon, and Tein 2008). In such cases, the total impact of the independent variable on the dependent variable is determined by the magnitude of its direct and indirect effects. Where the two effects are equal in size and with different signs, the total effect of the independent variable (cost leadership) on the dependent variable (lean service) will be zero and this may explain why some scholars found no relationship between cost leadership and lean practices (e.g. Ward et al. 2007; Baines and Langfield-Smith 2003; Chenhall and LangfieldSmith 1998). Thus, our analysis indicates that lean service and cost leadership are compatible and the direct positive relation detected in this study supports that. However, the adoption of an incompatible costing system (i.e. TCS) by some cost leaders may hinder the implementation of lean practices as also suggested in this study and this underlines the importance of considering the role of costing systems in order to better understand the business strategy-lean service association. The very limited research in this area has made it very difficult to find a cost leadership company which has experienced problems with lean practices due to its incompatible costing system. However, the cases reported by Datar et al. (1991) and Cooper and Maskell (2008) explained how TCSs can turn a successful lean program into a failure, leading to questioning its effectiveness and finally abandoning it. These case studies provide some support to the conclusion made in this study although they did not refer to the type of business strategy adopted by the companies under investigation.

For service managers adopting a cost leadership strategy, the above discussion carries a significant implication. Although cost leaders may obtain relatively accurate cost information from TCSs and at a lower cost (as discussed before), they may have to forgo the proven benefits 
of lean service if they continue to use such costing systems (Li et al. 2012, Cooper and Maskell 2008; Datar et al. 1991). For service managers adopting a differentiation strategy, the results confirm the validity of their choice of using $\mathrm{ABC}$ in the lean environment as $\mathrm{ABC}$ supports lean practices and helps companies to realise their benefits (Banker, Bardhan, and Chen 2008; Baines and Langfield-Smith 2003).

\section{Conclusion, limitations and future research}

This article sought to investigate the mechanism through which business strategy and $\mathrm{ABC}$ affect lean service, its implementation level and relationship with performance. Six hypotheses were developed and tested using PLS-SEM and data from 99 UK service firms. The results confirmed the effect of lean service on firm financial performance. Further, ABC was found to have a critical and supporting role in the lean service environment and lean practices mediated its impact on firm performance. Regarding the strategy-lean association, both cost leadership and differentiation strategies were directly and positively related to lean practices. However, in contrast to the indirect positive impact of differentiation strategy on lean practice via $\mathrm{ABC}$, an indirect negative effect was confirmed in the case of cost leadership strategy because of its reliance on TCSs which had a detrimental effect on lean practices. Therefore, whilst the ABC variable in the model partially mediated the differentiation strategy-lean practices relationship, it led to a situation of inconsistent mediation in the case of the cost leadership-lean relationship.

This study has similar limitations to other cross-sectional studies. Adopting a longitudinal methodology could significantly improve our confidence in the results. This would enable researchers to examine the impact of changes in costing systems on the effectiveness of lean 
practices. The relatively small sample could also be an issue in this study and therefore generalisation of the findings should be understood in light of this sample size. Future research on a larger sample size would supplement the findings of the current study and provide more generalisable results. Moreover, the reliance on single-item measures from a single respondent may be another limitation. However, this is a common method of measurement that has been used by several researchers in the existing literature (e.g. Nielsen, Kristensen, and Grasso 2018; Banker, Bardhan, and Chen, 2008), and the subjective measures were supplemented with objective measures on firm performance. Endogeneity is another problem which faces most empirical survey studies including this one. However, to partially address this problem, the effect of past performance was accounted for.

Despite the above limitations, this study has improved our theoretical understanding of the relationships between lean practices, business strategy and ABC rarely examined simultaneously in one model. In addition, through the simultaneous examination of these variables, we are now aware of the mediating role of $\mathrm{ABC}$ in the lean-strategy association and the mediating role of lean practice in the ABC-performance association. Such awareness was critical in explaining the mixed results reported in different streams of literature.

Future research may examine through longitudinal case studies the interesting case of inconsistent mediation detected in this study. Specifically, insightful research may provide more information on the experience of cost leaders with lean practices over time with focus on the effectiveness of these practices. Finally, this study offered insights into the possible contribution $\mathrm{ABC}$ can make in the lean environment. Interesting future research may focus on the newly 
developed concept of lean accounting as very limited evidence is currently available in this respect. Our sample firms indicated that lean accounting was not in use at the time of our survey. Hence, it would be interesting to shed more light on this system and understand why companies are still reluctant to use it.

\section{Acknowledgement}

I would like to thank Professors Afshin Mansouri, David Gallear, John Cullen, Josephine Maltby and the two anonymous reviewers for their useful comments on this paper.

\section{References}

Abu Mansor, N.N., M. Tayles, and R. Pike. 2012. Information Usefulness and Usage in Business Decision-Making: An Activity-Based Costing (ABC) Perspective. International Journal of Management, 29 (1), 19-32.

Agarwal, R., R. Green, P. J. Brown, H. Tan, and K. Randhawa. 2013. Determinants of quality management practices: An empirical study of New Zealand manufacturing firms. International Journal of Production Economics, 142 (1), 130-145.

Allway, M., and S. Corbett. 2002. Shifting to lean service: Stealing a page from manufacturers' playbooks. Journal of Organizational Excellence, 21 (2), 45-54

Al-Omiri, M., and C. Drury. 2007. A survey of factors influencing the choice of product costing systems in UK organizations. Management Accounting Research, 18 (4), 399-424.

Alsmadi, M., A. Almani, and R. Jerisat. 2012. A comparative analysis of Lean practices and performance in the UK manufacturing and service sector firms. Total Quality Management and Business Excellence, 23 (3-4), 381-396.

Atkinson, P. 2004. Creating and Implementing Lean Strategies. Management Services, 48 (2), 18-21.

Auzair, S.M., and K. Langfield-Smith. 2005. The effect of service process type, business strategy and life cycle stage on bureaucratic MCS in service organizations. Management Accounting Research, 16 (4), 399-421.

Baines, A., and K. Langfield-Smith. 2003. Antecedents to management accounting change: a structural equation approach. Accounting, Organizations and Society, 28 (7-8), 675-698.

Banker, R.D., I. R. Bardhan, and T. Y. Chen. 2008. The role of manufacturing practices in mediating the impact of activity-based costing on plant performance. Accounting, Organizations and Society, 33 (1), 1-19.

Bellisario, A., and A. Pavlov. 2018. Performance management practices in lean manufacturing organizations: a systematic review of research evidence. Production, Planning and Control, 29 (5), 1-19

Ben-Arieh, D., and L. Qian. 2003. Activity-based cost management for design and development stage. International Journal of Production Economics, 83 (2), 169-183. 
Bhasin, S. 2012. Performance of Lean in large organisations. Journal of Manufacturing Systems, 31 (3), 349- 357.

Bhimani, A.M., M. Gosselin, and M. Ncube. 2005. Strategy and activity based costing: a cross national study of process and outcome. International Journal of Accounting, Auditing and Performance Evaluation, 2 (3), 187-205.

Bowen, D.E., and W. E. Youngdahl. 1998. Lean service in defense of a production-line approach. International Journal of Service Industry Management, 9 (3), 207-225.

Carr, L., W. Lawler, and J. Reny. 2012. Rational expense reduction Lean budgeting at Irving Oil. The Journal of Corporate Accounting and Finance, 23 (3), 61-69.

Chenhall, R. H. 2003. Management controls systems design within its organizational context: Findings from contingency-based research and directions for the future. Accounting, Organizations and Society, 28 (2-3), 127-168.

Chenhall, R.H., and K. Langfield-Smith. 1998. The relationship between strategic priorities, management techniques and management accounting: an empirical investigation using a systems approach. Accounting, Organizations and Society, 23 (3), 243-264.

Chong, V. K., and K. M. Chong. 1997. Strategic Choices, Environmental Uncertainty and SBU Performance: A Note on the Intervening Role of Management Accounting Systems. Accounting and Business Research, 27 (4), 268-276.

Cooper, R., and R. Kaplan. 1992. Activity-Based Systems: Measuring the Costs of Resource Usage. Accounting Horizons, 6 (3), 2-13.

Cooper, R., and B. Maskell. 2008. How to Manage Through Worse-Before-Better. MIT Sloan management review, 49 (4), 58-65.

Craighead, C.W., G. T. M. Hult, and D. J. Ketchen. 2009. The effects of innovation-cost strategy, knowledge, and action in the supply chain on firm performance. Journal of Operations Management, 27 (5), 405-421.

Cua, K.O., K. E. McKone, and R. G. Schroeder. 2001. Relationships between implementation of TQM, JIT, and TPM and manufacturing performance. Journal of Operations Management, 19 (6), 675-694.

Datar, S., S. Kekre, M. Mukhopadaya, and E. Svaan. 1991. Overloaded Overheads: Activity-Based Cost Analysis of Material Handling in Cell Manufacturing. Journal of Operations Management, 10 (1), 119-137.

De Leeuw, S., and J. P. van den Berg. 2011. Improving operational performance by influencing shopfloor behavior via performance management practices. Journal of Operations Management, 29 (3), 224-235.

Falk, R.F., and N. B. Miller. 1992. A primer for soft modeling. Akron, OH: University of Akron press.

Fullerton, R. R., C. S. McWatters, and C. Fawson. 2003. An examination of the relationships between JIT and financial performance. Journal of Operations Management, 21 (4), 383-404.

Fullerton, R.R., and C. S. McWatters. 2004. An empirical examination of cost accounting practices used in advanced manufacturing environments. Advances in Management Accounting, 12, 85113

Fullerton, R.R., F. A. Kennedy, and S. A. Widener. 2014. Lean manufacturing and firm performance: The incremental contribution of lean management accounting practices. Journal of Operations Management, 32 (7-8), 414-428.

Fullerton, R.R., F. A. Kennedy, and S. A. Widener. 2013. Management accounting and control practices in a lean manufacturing environment. Accounting, Organizations and Society, 38 (1), 
$50-71$.

Galeazzo, A., and A. Furlan. 2018. Lean bundles and configurations: a fsQCA approach. International Journal of Operations and Production Management, 38 (2), 513-533.

Gosselin, M. 1997. The effect of strategy and organizational structure on the adoption and implementation of activity-based costing. Accounting, Organizations and Society, 22 (2), 105122.

Guest, D.E., J. Michie, N. Conway, and M. Sheehan. 2003. Human Resource Management and Corporate Performance in the UK. British Journal of Industrial Relations, 41 (2), 291-314.

Gupta, A. K., and V. Govindarajan. 1984. Business unit strategy, managerial characteristics, and business unit effectiveness at strategy implementation. Academy of Management Journal, 27 (1), $25-41$.

Gurd, B., M. Smith, and A. Swaffer. 2002. Factors impacting on accounting lag: An exploratory study of responding to TQM. The British Accounting Review, 34 (3), 205-221.

Hadid, W., and A. Mansouri. 2014. The lean-performance relationship in services: A theoretical model. International Journal of Operations and Production Management, 34 (6), 750-785.

Hadid, W., A. Mansouri, and D. Gallear. 2016. Is lean service promising? A socio-technical perspective. International Journal of Operations and Production Management, 36 (6), 1-25.

Hair, J.F., C. M. Ringle, and M. Sarstedt. 2011. PLS-SEM: Indeed a silver bullet. Journal of Marketing Theory and Practice, 19 (2), 139-151.

Hair, J.F., M. Sarstedt, and C. M. Ringle. 2012. An assessment of the use of partial least squares structural equation modeling in marketing research. Journal of the Academy of Marketing Science, 40 (3), 414-433.

Hair, Joseph F, William C. Black, Barry J.Babin, and Rolph E. Anderson. 2010. Multivariate Data Analysis. A Global Perspective, 7th edition. New Jersey: Pearson Education, Inc

Hallgren, M., and J. Olhager. 2009. Lean and agile manufacturing: external and internal drivers and performance outcomes. International Journal of Operations and Production Management, 29 (10), 976-999.

Hines, P., and N. Rich. 1997. The seven value stream mapping tools. International Journal of Operations and Production Management, 17 (1), 46-64.

Hitt, M.A., R. D. Ireland, and R. E. Hoskisson. 2016. Strategic Management: Concepts and Cases, 12th ed., Cengage Learning, Mason, $\mathrm{OH}$.

Inman, R.A., R. S. Sale, K. W. Green Jr, and D. Whitten. 2011. Agile manufacturing: Relation to JIT, operational performance and firm performance. Journal of Operations Management, 29 (4), 343-355.

Innes, J., and F. Mitchell. 1995. A survey of activity-based costing in the U.K.'s largest companies. Management Accounting Research, 6 (2), 137-153.

Ittner, C. D. 1999. Activity-based costing concepts for quality improvement. European Management Journal, 17 (5), 492-500.

Ittner, C.D., W. N. Lanen, and D. F. Larcker. 2002. The Association Between Activity-Based Costing and Manufacturing Performance. Journal of Accounting Research, 40 (3), 711-726.

Johnson, T., and R. Kaplan. 1987. The Rise and Fall of Management Accounting. Management Accounting, 68 (7), 22-29.

Joshi, M.P., R. Kathuria, and S. J. Porth. 2003. Alignment of strategic priorities and performance: an integration of operations and strategic management perspectives. Journal of Operations Management, 21 (3), 353-369. 
Kaplan, R.S., and D. P. Norton. 1992. The balanced scorecard-measures that drive Performance. Harvard Business Review, January-February, 70-80.

Kaplan, R.S., and D. P. Norton. 1996. Using the Balanced Scorecard as a Strategic Management System. Harvard Business Review, January-February, 150-161.

Kennedy, F.A., and S. K. Widener. 2008. A control framework: insights from evidence on lean accounting. Management Accounting Research, 19 (4), 301-323.

Kim, D.U., V. Kumar, and U. Kumar. 2012. Relationship between quality management practices and innovation. Journal of Operations Management, 30 (4), 295-315.

Krafcik, J. F. 1988. Triumph of the lean production system. Sloan Management Review, 30 (1), 4152.

Kroes, J.R., S. and Ghosh. 2010. Outsourcing congruence with competitive priorities: Impact on supply chain and firm performance. Journal of Operations Management, 28 (2), 124-143.

Kumar, A., and R. Telang. 2011. Product Customization and Customer Service Costs: An Empirical Analysis. Manufacturing and Service Operations Management, 13 (3), 347-360.

Langfield-Smith, K. 1997. Management control systems and strategy: a critical review. Accounting, organizations and society, 22(2), 207-232.

Lee, L., S. Petter, D. Fayard, and S. Robinson. 2011. On the use of partial least squares path modeling in accounting research. International Journal of Accounting Information Systems, 12 (4), 305328.

Lei, D., M. M. Hitt, and J. D. Goldhar. 1996. Advanced Manufacturing Technology: Organizational Design and Strategic Flexibility. Organization Studies, 17 (3), 501-523.

Li, X., R. Sawhney, E. J. Arendt, and K. Ramasamy. 2012. A comparative analysis of management accounting systems' impact on lean implementation. International Journal of Technology Management, 57 (1-3), 33-48.

MacKinnon, D.P., J. L. Krull, and C. M. Lockwood. 2000. Equivalence of the mediation, confounding and suppression effect. Prevention Science, 1 (4), 173-181.

Maiga, A.S., and F. A. Jacobs. 2008. Extent of ABC Use and Its Consequences. Contemporary Accounting Research, 25 (2), 533-566.

Maiga, A.S., A. Nilsson, F. A. and Jacobs. 2014. Assessing the interaction effect of cost control systems and information technology integration on manufacturing plant financial performance. The British Accounting Review, 46 (1), 77-90.

Malhotra, M.K., C. Singhal, G. Shang, and R. E. Ployhart. 2014. A critical evaluation of alternative methods and paradigms for conducting mediation analysis in operations management research. Journal of Operations Management, 32 (4), 127-137.

Malmi, T. 1999. Activity-based costing diffusion across organizations: an exploratory empirical analysis of Finnish firms. Accounting, Organizations and Society, 24 (8), 649-672.

Melin, M., and H. Barth. 2018. Lean in Swedish agriculture: strategic and operational perspectives. Production Planning and Control, 29 (10), 845-855.

Mia, L., and L. Winata. 2008. Manufacturing strategy, broad scope MAS information and information and communication technology. The British Accounting Review, 40 (2), 182-192.

Miles, R.W., and C. C. Snow. 1978. Organizational strategy, structure and process. New York: McGraw Hill.

Miller, A., and G. G. Dess. 1993. Assessing Porter's (1980) model in terms of its generalizability, accuracy and simplicity. Journal of Management Studies, 30 (4), 553-585.

Mishra, B., and I. Vaysman. 2001. Cost-System Choice and Incentives-Traditional vs. Activity-Based 
Costing. Journal of Accounting Research, 39 (3), 619-641.

Naranjo-Gil, D., V. S. Maas, and F. G. H. Hartmann. 2009. How CFOs determine management accounting innovation: an examination of direct and indirect effects. European Accounting Review, 18(4), 667-695.

Negrão, L. L. L., M. G. Filho, and G. Marodin. 2017. Lean practices and their effect on performance: a literature review. Production Planning and Control, 28 (1), 33-56.

Nielsen, H., T. B. Kristensen, and L. P. Grasso. 2018. The performance effects of complementary management control mechanisms. International Journal of Operations and Production Management, (In press).

Nunnally, J. 1978. Psychometric Theory, second ed. McGraw-Hill, New York.

Patterson, M.G., M. A. West, and T. D. Wall. 2004. Integrated manufacturing, empowerment and company performance. Journal of Organizational Behavior, 25 (5), 641-665.

Piercy, N., and N. Rich. 2009. Lean transformation in the pure service environment: the case of the call service centre. International Journal of Operations and Production Management, 29 (1), 5476.

Podsakoff, P.M., S. B. Mackenzie, J. Y. Lee, and N. P. Podsakoff. 2003. Common method biases in behavioral research: a critical review of the literature and recommended remedies. Journal of Applied Psychology, 88 (5), 879-903.

Porter, M. 1980. Competitive Strategy, Free Press. New York.

Porter, M. 1985. Competitive advantage: creating and sustaining superior performance, Free Press. New York.

Porter, M. 1991. Towards a Dynamic Theory of Strategy. Strategic Management Journal, 12 (special issue), 95-117.

Preacher, K.P., and A. F. Hayes. 2008. Asymptotic and resampling strategies for assessing and comparing indirect effects in multiple mediator models. Behavior Research Methods, 40 (3), 879-891.

Qi, Y., X. Zhao, and C. Sheu. 2011. The Impact of Competitive Strategy and Supply Chain Strategy on Business Performance: The Role of Environmental Uncertainty. Decision Sciences, 42 (2), 371-389.

Qian, L., and D. Ben-Arieh. 2003. Parametric cost estimation based on activity-based costing: A case study for design and development of rotational parts. International Journal of Production Economics, 113 (2), 805-818.

Scherrer-Rathje, M., T. A. Boyle, and P. Deflorin. 2009. Lean, take two! Reflections from the second attempt at lean implementation, Business Horizons, 52 (1), 79-88.

Schoute, M. 2011. The relationship between product diversity, usage of advanced manufacturing technologies and activity-based costing adoption. The British Accounting Review, 43 (2), 120134.

Shah, R., and P. T. Ward. 2003. Lean manufacturing: context, practice bundles, and performance. Journal of Operations Management, 21 (2), 129-149.

Shamsuzzaman, M., M. Alzeraif, I. Alsyouf, and M. B. C. Khoo. 2018. Using Lean Six Sigma to improve mobile order fulfilment process in a telecom service sector. Production Planning and Control, 29 (4), 301-314.

Swank, C. K. 2003. The Lean Service Machine. Harvard Business Review, 81 (10), 123-129.

Swink, M., and B. W. Jacobs. 2012. Six Sigma adoption: Operating performance impacts and contextual drivers of success. Journal of Operations Management, 30 (6), 437-453. 
Taylor, A.B., D. P. MacKinnon, and J. Tein. 2008. Tests of the three-path mediated effect. Organizational Research Methods, 11 (2), 241-269.

Tezel, A., L. Koskela, and Z. Aziz. 2018. Lean thinking in the highways construction sector: motivation, implementation and barriers. Production Planning and Control, 29 (3), 247-269.

Venkatraman, N., and V. Ramanujam. 1986. Measurement of business performance in strategy research: A comparison of approaches. Academy of management review, 11 (4), 801-814.

Ward, P.T., J. K. McCreery, and G. Anand. 2007. Business strategies and manufacturing decisions: An empirical examination of linkages. International Journal of Operations and Production Management, 27 (9), 951-973.

Womack, J. P., and D. T. Jones. 1996. Beyond Toyota: How to Root Out Waste and Pursue Perfection. Harvard Business Review, 74 (5), 140-158.

Appendix

1. "Indicate the extent to which your firm has implemented the following practices: (tick one option) (Check the glossary sheet for a definition of each expression if needed)

\begin{tabular}{lll}
\hline & Scale (1) No implementation & $\begin{array}{c}\text { (2) Considering } \\
\text { Substantially }\end{array}$ \\
\hline 1 & (3) Beginning (4) Partially \\
2 & Automation \\
3 & Group technology \\
4 & Improving facility layout \\
5 & Just in Time \\
6 & Kaizen blitz \\
7 & Policy deployment/Hoshin Kanri \\
8 & Pull system \\
9 & Quality function deployment \\
10 & Root cause analysis \\
11 & Total preventive maintenance \\
12 & Value stream mapping \\
13 & Visualisation \\
14 & Work load balancing \\
15 & Mistakes proofing/Poka-Yoke \\
16 & Quick set up time \\
17 & Small lots \\
18 & Continuous improvement \\
19 & Process redesign \\
20 & Standardisation \\
21 & Kanban \\
22 & Single piece flow \\
23 & Takt time \\
\hline
\end{tabular}


2. Has your firm implemented lean system? Yes No If your answer is $\boldsymbol{Y E S}$, indicate year initiated

3. Indicate by circling the costing system that is in use at your firm:

(1) Variable costing

(2) full absorption costing

(3) Activity-based costing

(4) Others

4. Please indicate the level of your firm's emphasis on the following activities: (tick one option)

\begin{tabular}{l}
\hline Scale (1) No emphasis (6) Highest level of emphasis \\
achieving lower cost of services than competitors \\
making service/procedures more cost efficient \\
improving the cost required for coordination of various services \\
improving the utilisation of available equipment, services and facilities \\
Introducing new services/procedures quickly \\
Providing services that are distinct from that of competitors \\
Offering a broader range of services than the competitors \\
Improving the time it takes to provide services to customers \\
Providing high quality services \\
Customising services to customers need \\
Providing after-sale services and support"
\end{tabular}


Table 1: The measurement model

\begin{tabular}{lccc}
\hline Construct & Loading & Composite reliability & AVE \\
\hline Process factor (PF) & & $\mathbf{0 . 8 8}$ & $\mathbf{0 . 5 4}$ \\
Automation & 0.70 & & \\
JIT & 0.69 & & \\
Pull system & 0.79 & \\
Quick setup & 0.73 & & \\
Small lots & 0.71 & \\
Work load balancing & 0.78 & $\mathbf{0 . 8 8}$ \\
Physical structure factor (PSF) & & \\
5Ss & 0.77 & \\
Group technology & 0.86 & \\
Improving facility layout & 0.86 & \\
Visualization & 0.69 & $\mathbf{0 . 8 2}$ \\
Customer value factor (CVF) & & & \\
Kaizen blitz & 0.77 & \\
Policy deployment & 0.78 & \\
Quality function deployment & 0.73 & \\
Value stream mapping & 0.64 & \\
Differentiation strategy & & \\
Differ1 & 0.72 & \\
Differ2 & 0.88 & \\
Differ3 & 0.86 & \\
Differ4 & 0.88 & \\
Differ5 & 0.83 & \\
Differ6 & 0.81 & \\
Differ7 & 0.82 & \\
Cost leadership strategy & & \\
Leader1 & 0.59 & \\
Leader2 & 0.77 & \\
Leader3 & 0.88 & \\
Leader4 & 0.86 & \\
\end{tabular}


Table 2: Correlations matrix ${ }^{\text {a }}$

\begin{tabular}{llcccccccccc}
\hline \multicolumn{1}{c}{ Construct } & 1 & 2 & 3 & 4 & 5 & 6 & 7 & 8 & 9 & 10 & 11 \\
\hline 1 ABC & $\mathbf{1}$ & & & & & & & & & & \\
2 & Differentiation strategy & $.27^{* *}$ & $\mathbf{0 . 8 3}$ & & & & & & & & \\
3 Past Profit per employee & 0.19 & 0.10 & $\mathbf{1}$ & & & & & & & \\
4 Past Return on capital employed & $-.21^{*}$ & -0.02 & 0.02 & $\mathbf{1}$ & & & & & & \\
5 Cost leadership strategy & $-.26^{* *}$ & 0.12 & -0.02 & 0.15 & $\mathbf{0 . 7 8}$ & & & & & \\
6 PF & 0.19 & $.30^{* *}$ & 0.09 & -0.04 & $.26^{*}$ & $\mathbf{0 . 7 4}$ & & & & \\
7 PSF & $.22^{*}$ & 0.15 & 0.12 & 0.03 & $.21^{*}$ & $.46^{* *}$ & $\mathbf{0 . 8 0}$ & & & \\
8 CVF & $.21^{*}$ & $.31^{* *}$ & 0.13 & 0.05 & 0.17 & $.46^{* *}$ & $.49^{* *}$ & $\mathbf{0 . 7 3}$ & & & \\
9 Profit per employee & 0.06 & 0.12 & $.55^{* *}$ & 0.11 & 0.04 & 0.12 & $.25^{*}$ & 0.18 & $\mathbf{1}$ & & \\
10 Return on capital employed & -0.15 & 0.04 & 0.03 & $.63^{* *}$ & 0.09 & 0.14 & 0.05 & 0.11 & $.27^{* *}$ & $\mathbf{1}$ & \\
11 Size & -0.17 & -0.13 & -0.12 & -0.01 & 0.06 & -0.08 & 0.11 & 0.08 & $-.26^{*}$ & 0.09 & $\mathbf{1}$ \\
\hline
\end{tabular}

** Correlation is significant at the 0.01 level (2-tailed).

*Correlation is significant at the 0.05 level (2-tailed).

${ }^{\text {a }}$ Squared root of average variance extracted on the diagonal 
Table 3: Results of hypotheses testing

Panel (A) Tests of the direct effects

\begin{tabular}{|c|c|c|c|c|c|c|}
\hline \multicolumn{7}{|c|}{ Panel (A) Tests of the direct effects } \\
\hline \multicolumn{7}{|c|}{ Endogenous variables } \\
\hline Exogenous variables & $\mathrm{ABC}$ & $\mathrm{PF}$ & PSF & $\mathrm{CVF}$ & $\begin{array}{l}\text { Profit per } \\
\text { employee }\end{array}$ & $\begin{array}{l}\text { Return on capital } \\
\text { employed }\end{array}$ \\
\hline \multicolumn{7}{|c|}{ Standardised coefficient $(\beta)$} \\
\hline Differentiation & $0.31 * * *$ & $0.21 *$ & 0.03 & $0.23 *$ & & \\
\hline Cost leadership & $(-0.3) * *$ & $0.29 * *$ & $0.29 * *$ & 0.20 & & \\
\hline $\mathrm{ABC}$ & & $0.20 *$ & $0.29 * *$ & $0.20 *$ & & \\
\hline PF & & & & & -0.01 & $0.20 * *$ \\
\hline PSF & & & & & $0.18^{*}$ & -0.07 \\
\hline CVF & & & & & 0.05 & 0.02 \\
\hline Size & & & & & & 0.11 \\
\hline Past profit per employee & & & & & $0.54 * * *$ & \\
\hline $\begin{array}{l}\text { Past return on capital } \\
\text { employed }\end{array}$ & & & & & & $0.64 * * *$ \\
\hline $\mathrm{R}^{2}$ & 0.16 & 0.18 & 0.13 & 0.15 & 0.34 & 0.44 \\
\hline Cross-validated redundancy & 0.162 & 0.080 & 0.065 & 0.062 & 0.343 & 0.460 \\
\hline
\end{tabular}

${ }^{*} \mathrm{p} \leq 0.05,{ }^{* *} \mathrm{p} \leq 0.01,{ }^{* * *} \mathrm{p} \leq 0.001$

Panel (B): Tests of the indirect effects

\begin{tabular}{lcc}
\hline Indirect paths & Indirect effect coefficient & $\begin{array}{c}\text { Average product term } \\
\text { (bootstrapping method) }\end{array}$ \\
\hline Cost leadership - ABC - PF & $-0.06^{*}$ & -0.06 \\
Cost leadership - ABC - PSF & $-0.09^{* * *}$ & -0.08 \\
Cost leadership - ABC - CVF & $-0.06^{*}$ & -0.06 \\
Differentiation - ABC - PF & $0.06^{*}$ & 0.07 \\
Differentiation - ABC - PSF & $0.09^{* * *}$ & 0.09 \\
Differentiation - ABC - CVF & $0.06^{*}$ & 0.06 \\
ABC - PF - return on capital employed & $0.04^{*}$ & 0.04 \\
ABC - PSF - profit per employee & $0.05^{*}$ & 0.04 \\
\hline
\end{tabular}

${ }^{*} \mathrm{p} \leq 0.10,{ }^{* *} \mathrm{p} \leq 0.05,{ }^{* * *} \mathrm{p} \leq 0.01$. ${ }^{a}$ A product term of the direct paths. 

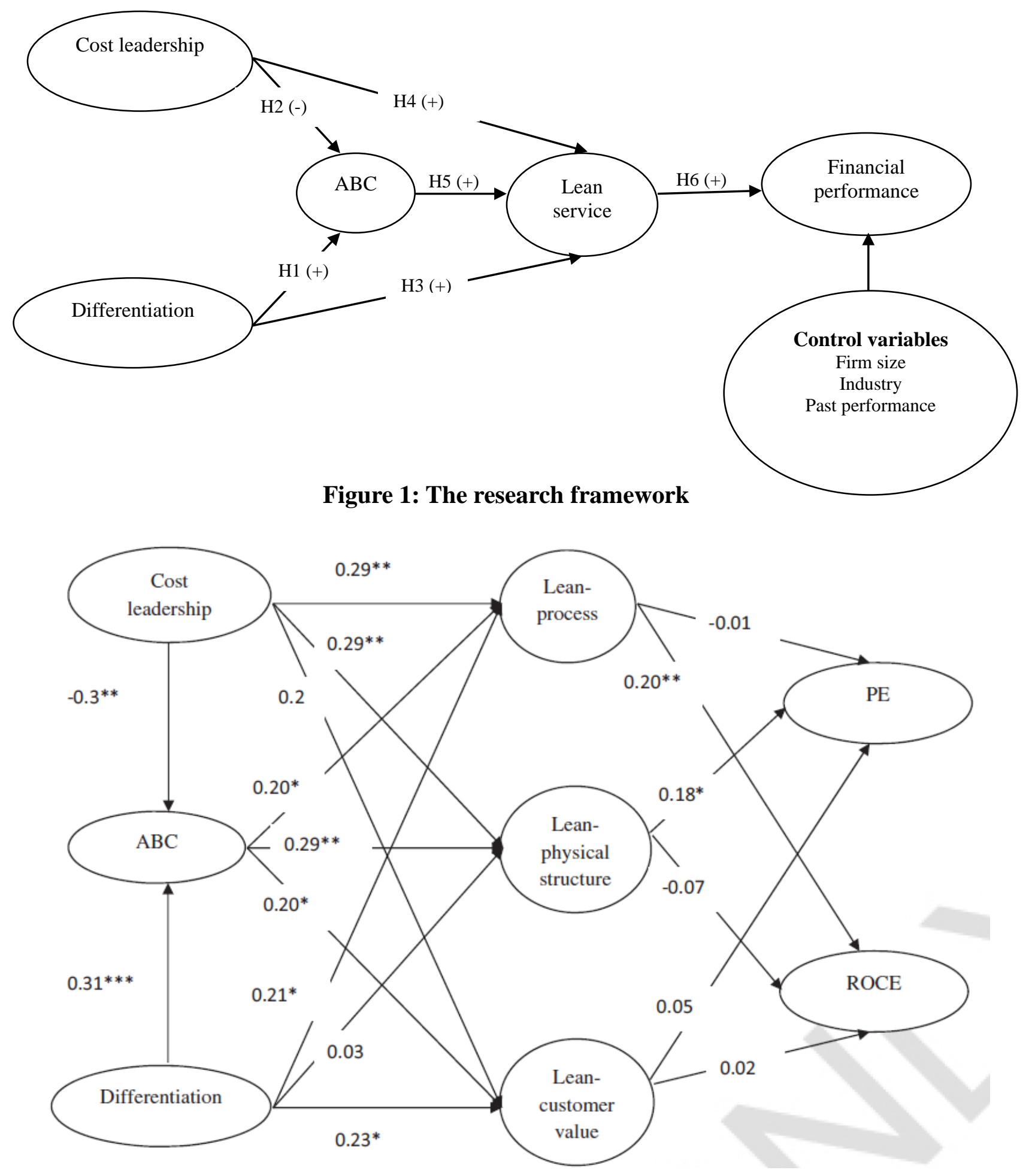

Figure 2: The structural model 